\title{
Study of Anxiety Levels among Occupational Therapy Students During Various Academic Assessments
}

\author{
Chirag Pincha' ${ }^{1}$ A.V. Anuja ${ }^{2}$, A. Sangeetha ${ }^{3}$, M. Karthika ${ }^{4}$, Samuel Sundar Doss ${ }^{5}$ \\ ${ }^{1}$ MBBS Student, ${ }^{2}$ Assistant Professor, ${ }^{3}$ Assistant Professor, Department of Physiology, Saveetha Medical college \\ \& Hospital, Thandalam, Chennai, ${ }^{4}$ Assistant Professor, Department of Physiology, Dhanalakshmi Srinivasan \\ Medical college \& Hospital, Perambalur, ${ }^{5}$ Tutor, Department of Physiology, Saveetha Medical college \& Hospital, \\ Thandalam, Chennai
}

\begin{abstract}
Test anxiety among university graduate students is significant and generates public interest. Test anxiety leads to cognitive symptoms such as racing thoughts, nausea, blankness and difficulty in retrieving information. When stress is experienced in excess it contributes to anxiety before and during exams and eventually affects academic performance.
\end{abstract}

Aim: The aim of the study is to evaluate the anxiety levels among occupational Therapy students during various academic assessments.

Method: A total of 160 Occupational Therapy Students participated in this study. The Anxiety Inventory was used to evaluate the anxiety level.

Results: The results indicated that anxiety affects students performance during theory \& practical assessments and was found to be statistically significant $(p<0.0001)$.

Recommendation: It is suggested that the pattern of conducting examinations may be modified to reduce student test anxiety.

Keywords: Test anxiety, Academic Assessments, Occupational Therapy Students.

\section{Introduction}

One of the most pervasive reactions that students have to encounter during different types of academic assessments is test anxiety ${ }^{(1)}$. Test anxiety by definition is a set of phenomenological, psychological, and behavioural responses that accompany possible negative consequences in a person ${ }^{(2)}$. Academic stress is an emerging problem across countries, cultures and must

\section{Corresponding Author:}

Dr. A.V. Anuja

Assistant Professor, Department of Physiology, Saveetha Medical College \& Hospital, Chennai e-mail: dr.anujasasi@gmail.com

Mobile No.: 9710702121 be viewed in detail ${ }^{(3)}$. Every student has a dream to lead success, family pride \& social mobility ${ }^{(4)}$. Test Anxiety is a bi-directional structure of affective \& Cognitive elements ${ }^{(5)}$. The cognitive component is Self cretinism and negative effects of failure during exams ${ }^{(6)}$. The student anxiety during the test causes an inability to recall information, rise in heart rate, nervousness, sweaty palms ${ }^{(7)}$.

Stress is not necessarily harmful, stress can motivate and it is a state of mental or emotional strain due to adverse or demanding circumstances ${ }^{(8)}$. The signs of stress which is experienced by most students before and during the examination are irregular sleep, tiredness, stomach upset, loneliness, feeling restless, difficulty in recalling whatever studied, panic when the question paper is given and difficulty answering it. The most stressful factors identified in educational institutions 
are evaluations and competitions between students and students' academic failures ${ }^{(9)}$. Identifying the influencing factors on student academic performance is a challenge for teachers ${ }^{(10)}$. Since the test scores are very significant for academic and carrier progress, the students are naturally under immense pressure to achieve high scores so the test anxiety becomes an universal experience in contemporary society, there seems to be some connection between the level of anxiety, experienced by the learners and their scores ${ }^{(11)}$.

Aside from academic factors, other influencing factors include financial factors, health problems ${ }^{(12)}$. This anxiety during or before exams have a major impact leading to lack of decision making and gives rise to nervousness and might also lead to suicide ${ }^{(13)}$. It is perceived that to reduce anxiety levels in students before \& during exams constructive learning method only will help the students to become independent and develop their own concepts pertaining on the subjects ${ }^{(14)}$. This anxiety many of the students face before their exams may interfere with their ability to score marks ${ }^{(15)}$. This study focuses on the anxiety levels of different age groups among occupational therapy students.

\section{Materials}

A cross-sectional questionnaire based study was conducted among occupational therapy students during the academic year 2019-20 at Saveetha Medical College and Hospital after obtaining ethical approval by the board of the institute (SMC/IEC/2019/22). Informed consent of the participants were obtained. A total of 160 students between 18-24 yrs participated in the study. Students on depression medication or any physical anxiety and depression were excluded from the study. The Test Anxiety Scale Questionnaire by Nist and Diehl (1990) was used to measure the level of anxiety. This scale consists of 10 items. Each item is scored based on how often they have experienced the mentioned signs of test anxiety. The scoring consisted of a 5-point scale, in which 1 was (never), and 5 (always) Items were then summed for a total score, which ranged between 10 and 50, where low scores between 10-19 indicated that students do not suffer from test anxiety, mid-scores between 20-35 indicated that although students exhibit some of the characteristics of test anxiety, the level of stress and tension is healthy and high scores over 35 showed that students experience unhealthy levels of anxiety. The questionnaire included demographic details, age, sex and symptoms before and during exams. Students those who are having history of neurological disorders, psychological disorders were excluded from the study. Signs of nervousness such as sweaty palms, shaky hands right before the test and panic attack before exam, going blank and not able to recall before the exam, trouble sleeping the night before the exam were collected. The data was analyzed using SPSS 20.1.

\section{Results}

The present study was done to assess anxiety among Occupational therapy students during different academic assessments and the results are as given below.

Table I : Demographic details

\begin{tabular}{|l|c|c|c|}
\hline & Theory & Practicals & Mean \& SD \\
\hline Age: & & & \\
18 yrs & 11 & 11 & $19.5 \pm 0.92$ (Theory) \\
$19 \mathrm{yrs}$ & 21 & 24 & $19.5 \pm 0.89$ (Practicals) \\
$20 \mathrm{yrs}$ & 44 & 44 & \\
\hline Sex: & & & \\
Male & $11 \%$ & $12 \%$ & \\
Female & $66 \%$ & $71 \%$ & \\
\hline
\end{tabular}

Table I show that more students were in the age group of 19 and 20 yrs with mean age $19 \pm 0.92$ years. of the participants $>65 \%$ were females.

Table II: Comparison of Anxiety scores between Theory and Practical Assessments

\begin{tabular}{|c|c|c|c|c|c|}
\hline Assessment & Low score & Moderate score & High Score & Chi-Square $\left(x^{2}\right)$ & P Value \\
\hline Theory $\mathrm{n}=77$ & $1 \%(0.96)$ & $4 \%(16.84)(9.79)$ & $72 \%(59.19)(2.77)$ & \multirow{2}{*}{24.333} & \multirow{2}{*}{$<0.5$} \\
\hline Practical $n=83$ & $1 \%(1.04)$ & $31 \%(18.16)(9.09)$ & $51 \%(63.81)(2.57)$ & & \\
\hline
\end{tabular}

Table II indicates a high degree of anxiety level (High score $>36-50$ ) among occupational therapy students during theory and practical assessment. The results show statistically significant. $\left(x^{2}=24.223, \mathrm{p}<0.5\right)$. 
Table III: Comparison of test anxiety among Occupational students during Theory \& Practical assessment.

\begin{tabular}{|c|c|c|c|}
\hline Parameters & $\begin{array}{c}\text { Theory } \\
(\text { Mean } \pm \text { SD) }\end{array}$ & $\begin{array}{c}\text { Practicals } \\
(\text { Mean } \pm \text { SD) }\end{array}$ & t-test \\
\hline $\begin{array}{l}\text { 1. Do you have any viable signs of nervousness such as sweaty palms, shaky } \\
\text { legs, right before the test? }\end{array}$ & $2.18 \pm 0.93$ & $2.44 \pm 1.00$ & $\begin{array}{l}\mathrm{p}=0.1150 \\
\mathrm{t}=1.5946\end{array}$ \\
\hline 2. Do you experience butterflies in your stomach before the exam & $2.00 \pm 0.86$ & $2.32 \pm 1.04$ & $\begin{array}{l}\mathrm{p}=0.039^{*} \\
\mathrm{t}=2.0744\end{array}$ \\
\hline 3. Do you feel nauseous before the exam? & $1.49 \pm 0.87$ & $2.90 \pm 0.94$ & $\begin{array}{l}\mathrm{p}=0.0001 * \\
\mathrm{t}=9.8069\end{array}$ \\
\hline 4. Does your mind go blank before the test? & $2.43 \pm 0.87$ & $2.35 \pm 0.89$ & $\begin{array}{l}\mathrm{p}=0.5672 \\
\mathrm{t}=0.5734\end{array}$ \\
\hline $\begin{array}{l}\text { 5. Do you remember the information that you blanked out in the exam hall } \\
\text { and remember as soon as you get out of the exam hall? }\end{array}$ & $2.41 \pm 0.82$ & $2.60 \pm 0.93$ & $\begin{array}{l}\mathrm{p}=0.2253 \\
\mathrm{t}=1.2225\end{array}$ \\
\hline $\begin{array}{l}\text { 6. Do you feel panicked knowing that the exam is time-limited and get more } \\
\text { nervous and write the exam worse }\end{array}$ & $2.20 \pm 0.80$ & $2.11 \pm 0.87$ & $\begin{array}{l}\mathrm{p}=0.4566 \\
\mathrm{t}=0.7483\end{array}$ \\
\hline $\begin{array}{l}\text { 7. Do you feel that you have done your test badly as soon as you leave the } \\
\text { exam? }\end{array}$ & $1.93 \pm 0.60$ & $2.15 \pm 0.88$ & $\begin{aligned} \mathrm{p} & =0.0399 * \\
\mathrm{t} & =2.0915\end{aligned}$ \\
\hline $\begin{array}{l}\text { 8. Do you feel nervous if the teacher stands next to you and then You can no } \\
\text { longer answer the questions? }\end{array}$ & $2.01 \pm 0.92$ & $2.23 \pm 0.92$ & $\begin{array}{l}\mathrm{p}=0.1290 \\
\mathrm{t}=1.5348\end{array}$ \\
\hline $\begin{array}{l}\text { 9. Do you feel you take most of the time in answering the questions or to } \\
\text { decide to hand in the paper or not? }\end{array}$ & $2.12 \pm 0.73$ & $2.07 \pm 0.78$ & $\begin{array}{l}\mathrm{p}=0.6890 \\
\mathrm{t}=0.4018\end{array}$ \\
\hline $\begin{array}{l}\text { 10. Do you feel constantly restless throughout the test (moving your feet } \\
\text { playing with your pen looking around the room and looking at the clock) }\end{array}$ & $2.12 \pm 0.92$ & $2.57 \pm 1.13$ & $\begin{aligned} \mathrm{p} & =0.0183^{*} \\
\mathrm{t} & =2.4123\end{aligned}$ \\
\hline 11. Do you feel that the invigilator/teacher is watching you? & $2.00 \pm 1.83$ & $2.27 \pm 0.96$ & $\begin{array}{l}P=0.0864 \\
t=1.7376\end{array}$ \\
\hline
\end{tabular}

Table III explains the student mean score of test anxiety relation between theory \& practical assessment.

The students faced the dreaded stomach before practical exam $(p=0.039 *)$, nausea $(p=0.0001 *)$, felt bad that they performed badly once they left the exam hall $\left(p=0.0399^{*}\right)$ and the students were constantly restless throughout the test $\left(\mathrm{p}=0.0183^{*}\right)$. The results were found to be statistically significant. The study also showed that students were more nervous to practical viva when compare to theory $52.4 \%$ were always nervous, $24.4 \%$ were often nervous and $18.3 \%$ were nervous sometimes during practical exam. A majority of participants never felt $51.2 \%$ that viva is easier to score marks than theory and practical exam $39 \%$ and $8.5 \%$ sometimes and often felt that viva is easier to score respectively. The results also showed that $30 \%$ of participants during Theory exam never felt has forgotten everything and may fail while the remaining $70 \%$ has forgotten and felt may fail. Also only $23.7 \%$ of participants do not feel more nervous sitting in first row during the exam remaining $76.3 \%$ feel more nervous sitting in first row.

\section{Discussion}

Exam anxiety may cause cognitive changes like difficulty in memorizing, inability to recall information's etc $^{(16)}$. Exceeding level of test anxiety results in mental, physical discomfort leading to focus problems and mental disruption ${ }^{(17)}$. Diversity of findings found in various researches indicates that different factors cause test anxiety in students ${ }^{(18)}$. Some authors suggest that test anxiety may worsen cognitive resources like attention and working memory, thus preventing students from concentrating on the exam ${ }^{(19)}$. The present study revealed that majority of participants were female in the mean age group of $19.5 \pm 0.92$ yrs (Table I). Studies repeatedly found due to higher levels of emotion in females generally report higher levels of anxiety ${ }^{(20)}$. Arch reported a very high prevalence of anxiety and depression (70\%) among medical students in Pakistan ${ }^{(21)}$. Another study has shown that academics and taking exams are the most powerful stresses in medical and paramedical students ${ }^{(22)}$. The result of this study was identified to have a high level of anxiety score and the 
highest mean score during practical examinations. This result is similar to David \& Ross $^{(23)}$ who proposed that a very high proportion of students had some form of test anxiety. More recent explanations refer to the fact that anxiety may affect students' motivation and undermine their learning strategies ${ }^{(24)}$. Whatever the cause, test anxiety may reduce students' academic achievement by interfering with their exam preparation, their performance while taking an exam, or both.

\section{Conclusion}

The study shows that anxiety affects students' performance during theory \& practical assessments and was found to be statistically significant. Hence it is suggested that the pattern of conducting examinations may be modified or certain relation techniques can be applied before exams to reduce student test anxiety.

Limitation of the Study: Further studies including a large number of medical and paramedical students should be done.

\section{Source of Funding: Self}

\section{Conflict of Interest: Nil}

Acknowledgment: We acknowledge great help received from the scholars whose articles are cited and included in the references of this manuscript.

\section{References}

1. Sarason IT, Test anxiety and the intellectual performance of college students. Journal of Educational Psychology, 1961; 52: 201-206.

2. Zeidner M. Test anxiety: The state of the art. New York: Plenum Press. Online http://www.uc.edu/ psc/sh/SH_Test_Anxiety.htm. 1998.

3. Wong PTP, Wong LCJ, Scot C et al. Beyond stress and coping: The positive psychology of transformation. Handbook of Multicultural perspectives on stress and coping. New York, NY: Springer.2006; 1-26.

4. Gow L, Balla J, Kember D et al . The learning approaches of Chinese people: A function of socialization processes and the context of learning. In M. H. Bond (Ed.)The handbook of Chinese psychology .New York: Oxford University Press. 1996.109- 123.

5. Morris L, Davis W, Hutchings $\mathrm{CH}$ et al. Cognitive and emotional components of anxiety: Literature review and a revised worry-emotionality scale. Journal of Educational Psychology, 1981; 73: 541555.

6. Zeidner M. Test anxiety: The state of the art. New York: Plenum Press.Onlinehttp://www.uc.edu/psc/ sh/SH_Test_Anxiety.htm.1998

7. Eysenck MW. Anxiety: The cognitive perspective. Hove, England: Erlbaum. 1992.

8. Mittal R, Kumar R. Exam stress in MBBS students and the method used for its alleviation. Int $\mathrm{J}$ Med and Dent Sci 2018; 7(1):1604-1608

9. Fairbrother K, Warn J. Workplace Dimensions, Stress and Job Satisfaction, J. Managerial Psychology.2003; 18(1): 8-21

10. Eggen P, Kauchak D. Educational Psychology: Windows on Classrooms. Upper Saddle River, NJ: Prentice Hall. 4th ed.1999

11. Bonde JP. Psychosocial factors at work and risk of depression: a systematic review of the epidemiological evidence. Occup Environ Med.2008; 65(7):438-45.

12. Ahmed W, Minnaert A, Kuyper H et al. Reciprocal relationships between mathself-concept and math anxiety. Learning and Individual Differences, 2011; 22: 385-389

13. Banerejee S, Youth and Exam Stress, Social Welfare, 2001;48:17.

14. Hyseni-Duraku, Interplay $Z$ between academic and personal factors in the academic performance of Bachelor students. 2014

15. Thangaraj S, Souza L. Prevalence of stress levels among first year medical undergraduate students. International Journal of Interdisciplinary and Multidisciplinary Studies, 2014;1:176-81.

16. Alam MM. Academic achievement in relation to socio-economic status, anxiety level and achievement motivation: A comparative study of Muslim and non-muslim school children of Uttar Pradesh. Doctoral Dissertation, Aligarh Muslim University .2001.

17. Hamzah F, Che Mat K, Bhagat V, Mahyiddin N. Test Anxiety and its Impact on first year University Students and the over View of mind and body Intervention to Enhance coping Skills in Facing Exam. Research J. Pharm. and Tech. 2018; 11(6):2220-2228.

18. Moadeli Z, Ghazanfari-Hesamabedi MA. Survey 
on the students' exam anxiety in the Fatemeh (P.B.A.H.) College of Nursing and Midwifery. Journal of Strides in Development of Medical Education, 2005; 1(2):65-72.

19. Eysenck, MW. Anxiety: The cognitive perspective. Hove, England: Erlbaum.1992

20. Deffenbacher JL. Worry and emotionality in test anxiety. In Sarason IG (Ed.), Test anxiety: Theory, research, and applications. New Jersey: Lawrence Erlbaum Associates. 1980.

21. Khan MS, Mahmood S, Badshah A et al. Prevalence of depression, anxiety and their associated factors among medical students in Karachi, Pakistan. J Pak Med Assoc. 2006; 56(12):583-586.
22. Fuad MD, Al-Zurfi BMN, Abdelqader MA et al. Prevalence and risk factors of stress, anxiety and depression among medical students of a private medical university in Malaysia. MJPHM.2016;16(3):87-92.

23. David B, Ross. College of Lake County, Grayslake, Illinois 847-543-2352. http://clcpage s.clcillinois. edu/home/cou052.2010

24. Linnenbrink EA, Schutz PA, Pekrun R The role of affect in student learning: A multi-dimensional approach to considering the interaction of affect, motivation, and engagement. In (Eds.), Educational psychology serie, 2007; 107-124. 